\title{
Rola posiadacza samoistnego w wybranych postępowaniach administracyjnych oraz procesach geodezyjno-prawnych
}

\author{
Agnieszka Pęska-Siwik, Piotr Benduch
}

\author{
AGH Akademia Górniczo-Hutnicza, Wydziat Geodezji Górniczej i Inżynierii Środowiska, \\ KatedraGeomatyki,e-mail: peska@agh.edu.pl,pbenduch@agh.edu.pl
}

Streszczenie: Prawo własności jest najważniejszym prawem rzeczowym. Jest ono fundamentem prawidłowo funkcjonującego społeczeństwa oraz zrównoważonej gospodarki. Obowiązujące przepisy w szczegółowy sposób opisują rolę właściciela w trakcie realizacji procesów geodezyjno-prawnych i postępowań administracyjnych związanych z nieruchomościami. Sytuacja komplikuje się w przypadku gruntów o nieuregulowanym stanie prawnym. Gdy nie jest możliwe ustalenie właściciela nieruchomości, wówczas w ewidencji wykazuje się dane osób i jednostek organizacyjnych, które tymi gruntami władają na zasadach samoistnego posiadania. Posiadacz samoistny faktycznie włada nieruchomością jak właściciel, jednak jego rola w postępowaniach administracyjnych takich jak rozgraniczenie nieruchomości, czy też w procesach geodezyjno-prawnych nie jest jednoznaczna.

Artykuł ma na celu scharakteryzowanie osoby posiadacza samoistnego oraz określenie roli jaką przyjmuje on m.in. przy ustaleniu przebiegu granic, rozgraniczeniu nieruchomości, wznowieniu znaków granicznych czy scaleniu i wymianie gruntów. Przedmiotem badań będą prawa i obowiązki posiadacza samoistnego. Wskazane zostaną możliwe rozwiązania legislacyjne, pozwalające na sprawne i skuteczne przeprowadzenie analizowanych procedur i postępowań, a zarazem zapewniające poszanowanie praw do nieruchomości.

Słowa kluczowe: własność, posiadanie samoistne, posiadanie zależne, kataster nieruchomości, ustalanie przebiegu granic.

\section{Wstęp}

Podczas wykonywania prac geodezyjnych związanych z ustaleniem przebiegu granic, jednym z kluczowych zagadnień jest określenie podmiotów, których dana sprawa dotyczy. W najprostszym z przypadków, wykonawca zobowiązany jest do powiadomienia właścicieli nieruchomości. Sytuacja komplikuje się gdy występują grunty o nieuregulowanym stanie prawnym lub gdy istnieją podmioty, którym przysługuje prawo do gruntu inne niż prawo własności.

Do prawidłowego określenia podmiotów związanych z daną procedurą geodezyjną konieczne jest uwzględnienie przepisów zawartych w różnych aktach prawnych. Rozpatrzyć należy regulacje zawarte m.in. w Kodeksie Cywilnym [Ustawa 1964], Kodeksie Postępowania Administracyjnego [Ustawa 1960], czy w Ustawie Prawo Geodezyjne i Kartograficzne [Ustawa 1989].

Główny cel niniejszego artykułu stanowi syntetyczna analiza praw i obowiązków posiadacza samoistnego w wybranych postępowaniach administracyjnych i procedurach geodezyjno-prawnych wraz ze wskazaniem możliwych kierunków zmian poszczególnych uregulowań prawnych, które mogłyby przyczynić się do poprawy w zakresie sprawnego i skutecznego przeprowadzania rozpatrywanych czynności z udziałem osoby posiadacza samoistnego. 


\section{Posiadanie w kodeksie cywilnym}

Kodeks cywilny, oprócz prawa własności, chroni również prawo posiadania. Posiadanie jest stanem faktycznym, w którym podmiot prawa cywilnego sprawuje we własnym interesie względnie trwałe, faktyczne władztwo nad rzeczą w zakresie prawa własności lub w zakresie innego prawa podmiotowego, umożliwiającego sprawowanie faktycznego władztwa nad cudzą rzeczą [1]. O ważności problemu posiadania świadczy również fakt zawarcia przez ustawodawcę przepisów chroniących to prawo. Ochrona posiadania została opisana w art. 342 Kodeksu Cywilnego: „Nie wolno naruszać samowolnie posiadania, chociażby posiadacz był w złej wierze".

W przepisach prawa cywilnego [Ustawa 1964] rozróżnia się dwa rodzaje posiadania posiadanie samoistne i posiadanie zależne:

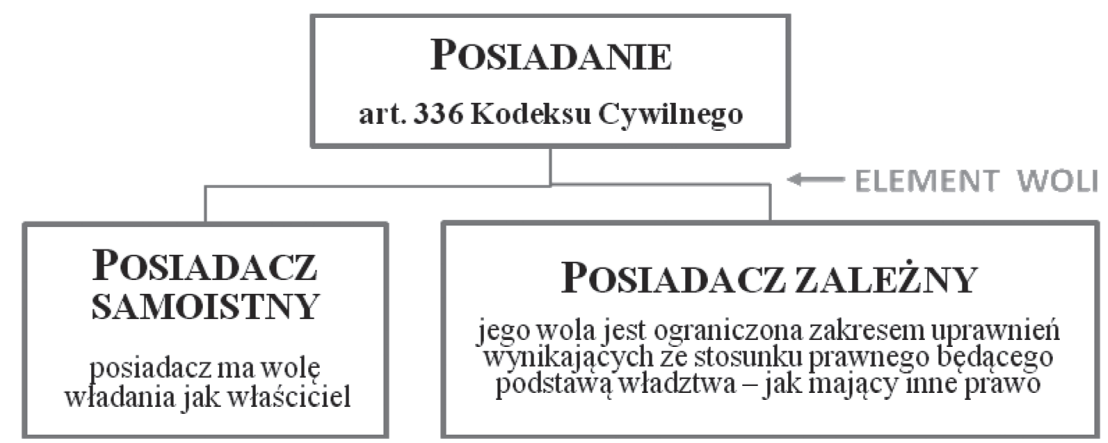

Rys. 1. Posiadanie według Kodeksu Cywilnego

Duże znaczenie dla wyróżnienia posiadania samoistnego i zależnego ma element woli [2]. W przypadku posiadania samoistnego posiadacz ma wolę władania jak właściciel, natomiast w przypadku posiadania zależnego jego wola jest ograniczona zakresem uprawnień wynikających ze stosunku prawnego będącego podstawą władztwa - jak mający inne prawo.

Posiadaczem samoistnym może być ten, kto rzeczą faktycznie włada jak właściciel. Jak wskazuje Gutkowski [3] posiadacz samoistny faktycznie włada rzeczą jak właściciel (zachowanie właścicielskie), ma rzeczywistą, faktyczną i ewidentną możność korzystania z rzeczy, jak również zachowuje się w sposób niepozwalający na odróżnienie posiadacza samoistnego od rzeczywistego właściciela (np. ogradza nieruchomość, uiszcza daniny publiczne).

Posiadaniem zależnym jest zwykle władztwo nad rzeczą, które wywodzi się ze stosunku prawnego, który daje posiadaczowi pewne, ściśle określone uprawnienia do rzeczy [4], [5]. Posiadaczem zależnym może być zatem użytkownik, zastawnik, najemca i dzierżawca. $\mathrm{W}$ badanym przypadku istotne będę prawa przypisane do gruntu, w związku z czym rozważania zostaną ograniczone przede wszystkim do osoby dzierżawcy.

\section{Posiadanie w ewidencji gruntów i budynków}

Ustawa Prawo Geodezyjne i Kartograficzne [Ustawa 1989] określa, że w przypadku gruntów, dla których ze względu na brak księgi wieczystej, albo innych dokumentów nie można ustalić ich właścicieli - w ewidencji gruntów i budynków ujawnia się osoby lub inne podmioty, które władają tymi gruntami na zasadach samoistnego posiadania. Posiadacz 
samoistny posiada również takie samo prawo jak właściciel do wystąpienia z wnioskiem o aktualizację danych ewidencyjnych. Ewidencja gruntów i budynków gromadzi również informacje dotyczące posiadaczy zależnych poprzez rejestrację umów dzierżawy. Dane te zawarte są m.in. w rejestrze gruntów [Rozporządzenie 2001].

Należy podkreślić, że prawo do uczestniczenia w postępowaniach administracyjnych i procedurach geodezyjno-prawnych, powinno przysługiwać tylko posiadaczom samoistnym oraz posiadaczom zależnym, którzy swoje prawo potwierdzili wpisem do bazy danych ewidencji gruntów i budynków. Przyjmując inne założenie, wykonawca prac geodezyjnych miałby duże trudności z ustaleniem stron postępowania oraz pozyskaniem danych niezbędnych do ich zawiadomienia o przeprowadzanych czynnościach. Podmioty posiadające prawo do nieruchomości, nie uwzględnione w ewidencji gruntów i budynków, mogłyby brać udział w postępowaniu, jednak bez przymiotu strony, a jedynie w charakterze świadka. Zaproponowane, dość surowe podejście do uwzględniania praw posiadacza samoistnego, wymusiłoby rejestrację tego prawa w ewidencji gruntów i budynków, a w konsekwencji mogłoby przyczynić się do uregulowania stanu prawnego nieruchomości.

\section{Podmioty postępowania administracyjnego}

Kodeks Postępowania Administracyjnego wyróżnia podmioty postępowania oraz uczestników postępowania, którym przyznaje różne prawa i obowiązki [Ustawa 1960], [6].

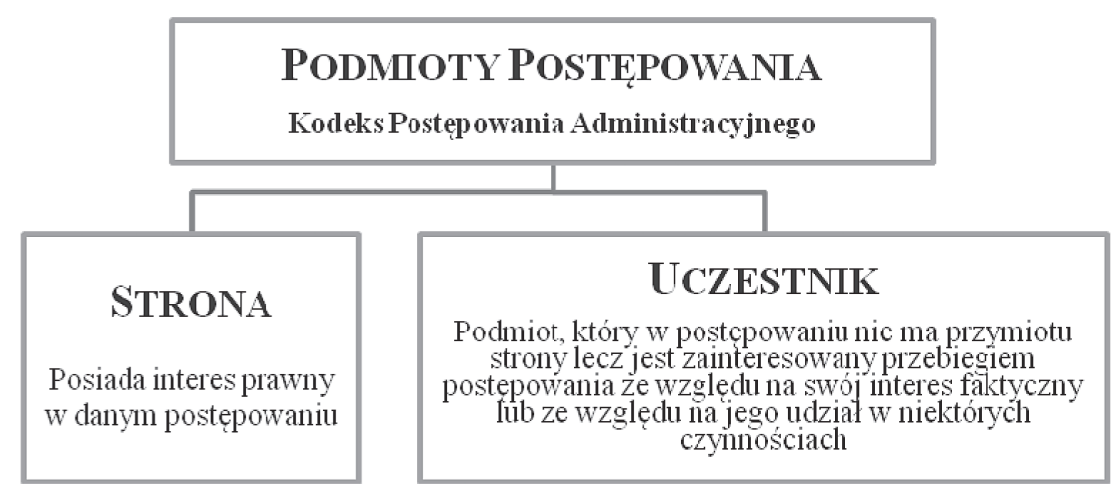

Rys. 2. Rodzaje podmiotów postępowania według Kodeksu Postępowania Administracyjnego

Podmiotem postępowania może być organ administracyjny właściwy do załatwienia sprawy oraz osoby, których interesy są chronione przez prawo w postępowaniu - strony i osoby na prawach strony. Stroną w postępowaniach administracyjnych oraz procedurach geodezyjno-prawnych bez wątpienia jest właściciel nieruchomości oraz użytkownik wieczysty. W przypadku posiadania samoistnego, jak wskazują orzeczenia sądu [II SA/Łd 61/10], [II OSK 195/16] może się zdarzyć, że za stronę ze względu na okoliczności zostanie uznana osoba legitymująca się innym prawem do nieruchomości. Obecna sytuacja prawna wymaga zatem odrębnej analizy dla każdego przypadku, pozwalającej na stwierdzenie w jakim charakterze posiadacz samoistny czy posiadacz zależny będzie występował w danej sprawie.

Uczestnikami postępowania są natomiast podmioty (osoby fizyczne, osoby prawne $\mathrm{i}$ inne jednostki organizacyjne), które w postępowaniu nie mają przymiotu strony lecz są zainteresowane przebiegiem postępowania ze względu na swój interes faktyczny lub ze względu 
na ich udział w niektórych czynnościach, np. świadkowie, biegli. Nie ulega wątpliwości, że w tym przypadku zarówno posiadacz samoistny jak i posiadacz zależny, ze względu na swój interes faktyczny będą uczestnikami postępowania.

\section{Rola posiadacza samoistnego podczas ustalenia przebiegu granic w trybie rozporządzenia w sprawie ewidencji gruntów i budynków}

Ewidencja gruntów i budynków gromadzi dane dotyczące przebiegu granic. Przebieg granic działek ewidencyjnych wykazuje się na podstawie dokumentacji geodezyjnej przyjętej do państwowego zasobu geodezyjnego i kartograficznego, sporządzonej w wyniku przeprowadzonych prac geodezyjno-prawnych takich jak podział czy rozgraniczenie nieruchomości. Jeżeli brak jest takiej dokumentacji lub zawarte w niej dane są niewiarygodne, wówczas dane dotyczące przebiegu granic działek ewidencyjnych pozyskuje się w wyniku pomiarów geodezyjnych poprzedzonych ustaleniem przebiegu granic.

Procedura ustalenia przebiegu granic, opisana w paragrafie 38 i 39 Rozporządzenia w sprawie ewidencji gruntów i budynków [Rozporządzenie 2001], zobowiązuje wykonawcę prac do zawiadomienia o przeprowadzonych czynnościach wszystkich właścicieli, użytkowników wieczystych oraz osoby władające tymi działkami na zasadach samoistnego posiadania. Zapis ten stawia na równi prawa właściciela z prawami posiadacza samoistnego. Potwierdzenie tej tezy, znajduje się również w kolejnym paragrafie: „,Ustalenia przebiegu granic działek ewidencyjnych, w tym położenia wyznaczających je punktów granicznych, dokonuje wykonawca na podstawie zgodnych wskazań właścicieli lub użtkowników wieczystych tych działek albo osób władajacych tymi działkami na zasadach samoistnego posiadania, potwierdzonych ich zgodnym oświadczeniem złożonym do protokotu ustalenia przebiegu granic działek ewidencyjnych.". Na tej podstawie można stwierdzić, że podczas ustalenia przebiegu granic, posiadacz samoistny jest stroną, na takich samych prawach jak właściciel nieruchomości. Podkreślić należy, że konieczne jest tu jednak udokumentowanie swojego prawa przez posiadacza samoistnego poprzez stosowny wpis w ewidencji gruntów i budynków. Można zatem domniemywać, że geodeta w toku omawianego procesu nie ma obowiązku ustalania osób władających gruntem na zasadach samoistnego posiadania. Przyjmuje w tym zakresie dane, które zostały ujawnione w katastrze. Posiadacz zależny może być natomiast wyłącznie uczestnikiem czynności ustalenia przebiegu granic działki w trybie rozporządzenie w sprawie ewidencji gruntów i budynków.

\section{Rozgraniczenie nieruchomości}

Rozgraniczenie nieruchomości jest postępowaniem mającym na celu ustalenie przebiegu granic, przede wszystkim w sytuacji, gdy granice te stały się sporne. Do 31 grudnia 2013 roku, tj. do momentu wejścia w życie nowelizacji rozporządzenia w sprawie ewidencji gruntów i budynków z dnia 29 listopada 2013 roku [Rozporządzenie 2013], rozgraniczenie obok modernizacji ewidencji gruntów i budynków było jedyną możliwą drogą do ustalenia przebiegu granic działki. Oznacza to, że nieruchomość podlegała rozgraniczeniu również niezależnie od wystąpienia sporu między sąsiadami, a proces ten bywał realizowany m.in. przed rozpoczęciem robót budowlanych dla potrzeb aktualizacji danych o granicach zawartych w katastrze i zwiększenia ich szeroko rozumianej wiarygodności. Rozgraniczenie może zostać także wszczęte z urzędu przy scaleniu gruntów bądź w przypadku, gdy potrzeby gospodarki narodowej lub interes społeczny uzasadniają przeprowadzenie rozgraniczenia. Procedura 
ta regulowana jest przez prawo geodezyjne i kartograficzne [Ustawa 1989] oraz akt wykonawczy do tej ustawy: Rozporządzenie Ministrów Spraw Wewnętrznych i Administracji oraz Rolnictwa i Gospodarki Żywnościowej z dnia 14 kwietnia 1999 r. w sprawie rozgraniczania nieruchomości [Rozporządzenie 1999]. Zapisy obu aktów prawnych, w większości przypadków, odnoszą się do pojęcia strony.

Ustawa Prawo Geodezyjne i Kartograficzne [Ustawa 1989] nie definiuje pojęcia strony na użytek postępowania rozgraniczeniowego. Niezbędnym wydaje się odniesienie do zapisu zawartego w Kodeksie Postępowania Administracyjnego [Ustawa 1960]. Prawo żądania rozgraniczenia nieruchomości jest uprawnieniem wynikającym przede wszystkim z prawa własności, lecz piśmiennictwo i orzecznictwo przyznaje również roszczenie o rozgraniczenie osobom uprawnionym rzeczowo. Jak wskazuje wyrok NSA z dnia 20 marca 2013 roku [I OSK 2418/11] w którym powołano się na orzeczenie Sądu Najwyższego z 7 sierpnia 2000 roku [I CKN 431/09], posiadacz samoistny nieruchomości może żądać rozgraniczenia dopóty, dopóki istnieje domniemanie, że jego posiadanie jest zgodne ze stanem prawnym. Uzasadnione wydają się jednak wątpliwości, czy ujawnienie w katastrze nieruchomości osoby posiadacza samoistnego będzie w tym względzie wystarczającą przesłanką, na co zwraca uwagę Wolanin [11]. Choć wpis danych prawnych do bazy ewidencji gruntów i budynków ma charakter urzędowy, to nie wynika z niego nawet domniemanie zgodności stanu obiektu z rzeczywistym stanem prawnym [7]. Do żądania rozgraniczenia nieruchomości uprawniony jest również użytkownik wieczysty [IV SA/Wa 255/16], [II SA/Łd 1077/97], podobnie jak osoba, której przysługuje ograniczone prawo rzeczowe do gruntu w oznaczonym zakresie, np. służebności [III SA/Kr 504/08].

W ocenie autorów, w świetle przytoczonego orzecznictwa sądów administracyjnych, posiadacz samoistny może zarówno zainicjować postępowanie w sprawie rozgraniczenia nieruchomości na skutek złożenia wniosku, jak również brać udział w czynnościach rozgraniczenia na prawach strony, analogicznie jak właściciel bądź użytkownik wieczysty. Warunkiem koniecznym jest jednak odpowiednie udokumentowanie faktu posiadania. Jest to o tyle istotne, że nadanie danemu podmiotowi uprawnień do wszczęcia postępowania administracyjnego nie w każdym przypadku będzie tożsame z automatycznym włączeniem tego podmiotu do postępowania w charakterze strony.

Na podstawie powyższych rozważań, można wskazać następujące strony postępowania rozgraniczeniowego, posiadające jednocześnie uprawnienie do żądania rozgraniczenia:

- właściciel nieruchomości lub użytkownik wieczysty nieruchomości,

- współwłaściciel lub współużytkownik wieczysty, jeżeli żądanie rozgraniczenia ma na celu zachowanie wspólnego prawa [Ustawa 1964],

- posiadacz samoistny, jeżeli przemawia za nim domniemanie posiadania zgodnego ze stanem prawnym [Ustawa 1964],

- osoba, której przysługuje cywilnoprawny tytuł do rozgraniczanych nieruchomości w postaci innego podmiotowego prawa rzeczowego ograniczonego, przypisanego do gruntu w oznaczonym zakresie (np. służebności) [III SA/Kr 504/08].

Stronami w postępowaniu rozgraniczeniowym nie są natomiast podmioty, którym przysługują prawa obligacyjne w stosunku do nieruchomości. Jak podano w [8], w przypadku umów najmu (za wyjątkiem najmu lokalu) i dzierżawy to na właścicielu spoczywa obowiązek zapewnienia najemcy czy dzierżawczy ochrony wobec osób trzecich, np. sąsiadów. Oddanie rzeczy (nieruchomości) w ramach umowy obligacyjnej nie pozbawia tym samym właściciela prawa do posiadania i to na nim ciąży obowiązek występowania przeciw osobom naruszającym uprawnienia osób wynikających z umów obligacyjnych w celu ochrony 
ich interesów. Kwestia ta często wzbudza jednak wiele wątpliwości, również ze względu na niektóre wyroki sądów administracyjnych, gdzie w gronie osób legitymujących się uprawnieniem do wszczęcia postępowania rozgraniczeniowego oraz posiadających przymiot strony obok właściciela, użytkownika wieczystego, posiadacza samoistnego i osób którym przysługuje ograniczone prawa rzeczowe, wymieniany jest również posiadacz zależny [III SA/Wr 146/04, IV SA/Wa 255/16].

Autorzy artykułu podzielają jednak pogląd, że stroną w postępowaniu rozgraniczeniowym nie jest najemca, dzierżawca, oraz osoba władająca nieruchomością na podstawie umowy użyczenia czy leasingu. Posiadacz zależny może być zatem tylko uczestnikiem tego postępowania, podobnie jak w przypadku czynności ustalenia przebiegu granic w trybie rozporządzenia w sprawie ewidencji gruntów i budynków. Analogiczna sytuacja występuje w przypadku posiadacza służebności. Jak wskazano w orzeczeniu WSA w Krakowie z 16 czerwca 2009 roku [III SA/Kr 504/08], korzystanie z cudzej nieruchomości w zakresie przejazdu i przechodu przez osoby, które nie mają tytułu cywilnoprawnego do tej nieruchomości nie przydaje tym osobom przymiotu interesu prawnego w rozumieniu art. 28 [Ustawa $1960]$.

Wartym zauważenia jest jednak fakt, wynikający z literalnego podejścia do przepisów. Ustalenie przebiegu granic w postępowaniu rozgraniczeniowym może nastąpić poprzez ustalenie granicy na podstawie „zgodnego oświadczenia stron”, strony mogą również zawrzeć ugodę. Treść aktu ugody odnosi się jednak do „działek będących własnością”, a na szkicu granicznym należy zawrzeć ,imiona i nazwiska właścicieli rozgraniczanych nieruchomości”. Sytuacją budzącą mniej wątpliwości byłoby stałe odnoszenie się do pojęcia strony w przepisach związanych z rozgraniczaniem nieruchomości. Istotne jest także, że nie każda osoba zawiadomiona o wszczęciu postępowania rozgraniczeniowego automatycznie staje się jego stroną [III SA/Kr 504/08]. Trzeba też przypomnieć, że obowiązek ustalenia stron postępowania rozgraniczeniowego spoczywa na organie prowadzącym to postępowanie, a nie na geodecie prowadzącym czynności ustalenia przebiegu granic na gruncie [9], [10].

\section{Wznowienie znaków granicznych}

Wznowienie znaków granicznych jest techniczną procedurą mającą na celu odtworzenie przesuniętych, uszkodzonych lub zniszczonych znaków granicznych, których położenie zostało uprzednio ustalone. Zgodnie z artykułem 38 prawa geodezyjnego i kartograficznego [Ustawa 1989], obowiązek ochrony znaków granicznych został nałożony zarówno na właścicieli nieruchomości, jak i osoby władające takimi gruntami. Wznowienie znaków granicznych przeprowadza wykonawca prac geodezyjnych na zlecenie zainteresowanych przywróceniem prawidłowego położenia tych znaków [Ustawa 1989]. Jak wskazuje Wolanin [11] ustawodawca nie posłużył się pojęciem „strona”, lecz pojęciem „zainteresowani”, które ma szersze znaczenie. Oznacza to, że zlecenie wykonania wznowienia znaków granicznych może nastąpić nie tylko przez właścicieli nieruchomości, lecz także przez inne osoby i podmioty, dla których wznowienie to ma wpływ na wykonywane przez nie uprawnienia. Można zatem stwierdzić, że osobą na zlecenie której wykonywane będzie wznowienie znaków granicznych może być zarówno posiadacz samoistny jak i posiadacz zależny. Takie rozwiązanie jest korzystne zarówno dla właścicieli jak i posiadaczy zależnych. Dzierżawca może zlecić wykonanie wznowienia znaków granicznych dla dzierżawionej działki bez udziału właściciela. Właściciel powinien jednak zostać zawiadomiony o przeprowadzanych czynnościach. Ponadto, do wprowadzenia ewentualnych zmian w ewidencji gruntów i budynków, które czasem występują przy wznowieniu, niezbędny jest wniosek właściciela działki. 
Problematyczne może natomiast wydawać się podjęcie czynności wznowienia znaków granicznych w przypadku nieruchomości o nieuregulowanym stanie prawnym. Odnosząc się jednak do art. 113 Ustawy o gospodarce nieruchomościami [Ustawa 1997], która stanowi jedyny akt prawny w którym zdefiniowano pojęcie nieruchomości o nieuregulowanym stanie prawnym można przyjąć, że takową nieruchomość bądź jej część będzie stanowić m.in. działka ewidencyjna, będąca przedmiotem władania ujawnionej w katastrze nieruchomości osoby posiadacza samoistnego. Wówczas nie ma wątpliwości, czy osoba ta jest uprawniona do zlecenia czynności wznowienia znaków granicznych geodecie uprawnionemu. Nie mniej jednak, w przypadku gdy dany podmiot nie ujawni swojego prawa w ewidencji gruntów i budynków, sprawa staje się już mniej jednoznaczna. Biorąc jednak pod uwagę, że wznowienie znaków granicznych jest czynnością czysto techniczną w wyniku której ustalona uprzednio granica nieruchomości nie powinna ulec przesunięciu, teoretycznie nie ma podstaw do tego, aby osoba wobec której istnieje domniemanie posiadania samoistnego nie mogła zostać zleceniodawcą tej czynności. Niezależnie od tego, czy działa w dobrej czy złej wierze, działania te w przypadku wznowienia znaków granicznych nie powinny przyczynić się do powstania szkody.

Rozpatrując natomiast wspomniane na wstępie postulaty zmierzające do wymuszenia rejestracji prawa posiadania samoistnego w ewidencji gruntów i budynków, najlepszym rozwiązaniem w ocenie autorów byłoby uznanie za osoby zainteresowane w rozumieniu art. 39 Prawa geodezyjnego i kartograficznego [Ustawa 1989] wyłącznie podmiotów ujawnionych w katastrze nieruchomości. Byłoby to również optymalne rozwiązanie w kontekście art. 39. ust. 3 [Ustawa 1989] zgodnie z którym o czynnościach wznowienia znaków granicznych geodeta ma obowiązek zawiadomić zainteresowane strony. Analogicznie jak w omówionych wcześniej procedurach i postępowaniach, nie sposób żądać od wykonawcy każdorazowej, pełnej analizy stanu prawnego nieruchomości dla potrzeb określenia listy osób koniecznych do zawiadomienia.

\section{Scalenie i wymiana gruntów}

Celem scalenia i wymiany gruntów jest tworzenie korzystniejszych warunków gospodarowania w rolnictwie i leśnictwie. Ustawa o Scaleniu i Wymianie Gruntów [Ustawa 1982], już w pierwszym artykule wskazuje, że mówiąc o właścicielu - rozumie się przez to również posiadacza samoistnego. Postawienie takiego warunku już na początku ustawy w bezpośredni sposób wskazuje na ważność osoby posiadacza samoistnego. Zarówno właściciel jak i posiadacz, będą w postępowaniu o scalenie i wymianę gruntów stronami tego postępowania. Jak wskazuje uchwała Sądu Najwyższego z dnia 20 lutego 2013 roku [III CZP 98/12], samoistny posiadacz nieruchomości objętej postępowaniem scaleniowym, który w zamian za tę nieruchomość obejmuje w posiadanie inną nieruchomość wydzieloną w tym postępowaniu, zachowuje ciągłość posiadania także wtedy, gdy nie był uczestnikiem tego postępowania jako właściciel.

Dalsze zapisy ustawy wprowadzają również pojęcie uczestnika scalenia - rozumie się przez to właściciela, użytkownika gruntu położonego na obszarze scalenia lub inwestora, a w przypadku gruntów stanowiących własność Skarbu Państwa lub jednostek samorządu terytorialnego także podmiot gospodarujący tymi gruntami. Uczestnikiem scalenia będzie zatem także posiadacz samoistny. Choć dzierżawca jest użytkownikiem gruntu, nie będzie on uczestnikiem scalenia. W przypadku tak istotnej zmiany związanej z położeniem posiadanych nieruchomości, jedynie właściciel i posiadacz samoistny mają prawo do wyrażania swoich opinii. 


\section{Wnioski końcowe}

1. W kodeksie cywilnym, oprócz prawa własności chronione jest również prawo posiadania. Wyróżnić można dwa rodzaje posiadania: posiadanie samoistne, kiedy to posiadacz samoistny ma wolę władania jak właściciel, oraz posiadanie zależne, kiedy wola posiadacza ograniczona jest zakresem uprawnień wynikających ze stosunku prawnego będącego podstawą władztwa.

2. Ustawa prawo geodezyjne i kartograficzne wskazuje, że w przypadku gruntów o nieuregulowanym stanie prawnym, w ewidencji ujawnia się osoby lub inne podmioty, które władają tymi gruntami na zasadach samoistnego posiadania. Niestety w praktyce rejestrowanie posiadania samoistnego wciąż nie jest regułą, między innymi ze względu na brak precyzyjnych regulacji dotyczących tego, na podstawie jakich dokumentów i dowodów fakt posiadania samoistnego może zostać zaewidencjonowany w katastrze nieruchomości. Odnosząc się do zasad aktualizacji danych ewidencyjnych zawartych w art. 24 Prawa geodezyjnego i kartograficznego [Ustawa 1989], można przyjąć, że podstawę najczęściej stanowić będzie prawomocne orzeczeniu sądu bądź wpis w innym rejestrze publicznym (księgi wieczyste).

3. Kodeks postępowania administracyjnego wyróżnia podmioty postępowania oraz uczestników postępowania, którym przyznaje różne prawa i obowiązki. Obecna sytuacja prawna wymaga zatem odrębnej analizy dla każdego przypadku, pozwalającej na stwierdzenie w jakim charakterze posiadacz samoistny czy posiadacz zależny będzie występował w danej sprawie.

4. Posiadacze samoistni i zależni powinni swoje prawo udokumentować stosownym wpisem do ewidencji gruntów i budynków. Tylko wtedy mogą być prawidłowo zawiadomieni o czynnościach i mogą brać w nich czynny udział.

5. Stroną w postępowaniu rozgraniczeniowym jest właściciel, jak również posiadacz samoistny. Posiadacz zależny może być tylko uczestnikiem tego postępowania. Taka sama sytuacja ma miejsce podczas ustalania przebiegu granic dla celów ewidencji gruntów i budynków.

6. Czynności wznowienia znaków granicznych, wszczyna się na wniosek zainteresowanej osoby. Tą osobą może być zarówno posiadacz samoistny jak i posiadacz zależny. Należy jednak dążyć do tego, aby osoby te mogły występować w roli zainteresowanych w rozumieniu art. 39 Prawa geodezyjnego i kartograficznego [Ustawa 1989] wyłącznie po uprzednim ujawnieniu w ewidencji gruntów i budynków.

7. Podczas scalenia i wymiany gruntów posiadacz samoistny traktowany jest tak samo jak właściciel nieruchomości. Jest on uczestnikiem scalenia.

8. Rolę jaką pełni posiadacz samoistny i posiadacz zależny $w$ omawianych postępowaniach administracyjnych i procedurach geodezyjno-prawnych, ostatecznie zaprezentowano w Tab. 1.

Tabela. 1. Rola posiadacza samoistnego i posiadacza zależnego w omawianych postępowaniach administracyjnych i procedurach geodezyjno-prawnych

\begin{tabular}{ccc}
\hline Rodzaj czynności & Posiadacz samoistny & Posiadacz zależny \\
\hline Ustalenie przebiegu granic & Strona & Uczestnik czynności \\
\hline Rozgraniczenie nieruchomości & Strona postępowania & Uczestnik postępowania, świadek \\
\hline Wznowienie znaków granicznych & Strona (zainteresowany) & Strona (zainteresowany) \\
\hline Scalenie i wymiana gruntów & $\begin{array}{c}\text { Strona postępowania } \\
\text { (uczestnik scalenia) }\end{array}$ & Uczestnik postępowania \\
\hline
\end{tabular}

Źródło: Opracowanie własne 


\section{Literatura}

[1] Osajda K. Tom II. Kodeks cywilny. Komentarz. Własność i inne prawa rzeczowe. Ustawa o księgach wieczystych i hipotece (art. 2-22, 65-111(1)). Ustawa o zastawie rejestrowym i rejestrze zastawów. Wydawnictwa C.H. Beck, Warszawa, 2017.

[2] Gniewek E., Machnikowski P. Kodeks cywilny. Komentarz. 8 wydanie. Wydawnictwa C.H. Beck, Warszawa, (2017).

[3] Gutkowski M. Kodeks cywilny. Tom I. Komentarz do art. 1-449(11). Seria: Duże Komentarze Becka. Wydawnictwa C.H. Beck, Warszawa (2016).

[4] Maśniak, J. Formy obrotu ziemiq rolnicza w Polsce. Zesz. Nauk. SGGW, Ekonomika i Organizacja Gospodarki Żywnościowej 72 (2008) 213-222.

[5] Trembecka A. Trwały Zarząd jako forma władania nieruchomościami publicznymi na przykładzie miasta Krakowa. Acta Sci. Pol. Administratio Locorum 16(3) (2017) 215-222.

[6] Adamiak B., Borkowski J. Postęowanie administracyjne i sqdowoadministracyjne. ISBN: 97883-8107-704-0, Wolters Kluwer, Warszawa, 2017.

[7] Hanus P., Hycner R., Kwartnik-Pruc A. Analiza terminologiczna wybranych problemów katastru i zagadnień pokrewnych. Cz. 1: Działka, granica, nieruchomość. Magazyn Geoinformacyjny Geodeta 11 (2013) 25-32.

[8] Felcenloben D. Rozgraniczenie nieruchomości. Teoria i praktyka z orzecznictwem sadowo-administracyjnym. Wydawnictwo Gall, Katowice, 2008.

[9] Pęska A. The role of the surveyor in real estate delimitation run during administrative and court procedure. Geomatics and Environmental Engineering, 8(2) (2014) 71-84.

[10] Bieda A., Pęska A., Szałajko A. Analiza czasu trwania postępowania w sprawie o rozgraniczenie nieruchomości. Acta Sci. Pol. Administratio Locorum 15(1) (2016) 15-29.

[11] Wolanin M. Podziały, scalenia i rozgraniczenia nieruchomości oraz procedury ewidencyjne. Wydanie 3. Wydawnictwa C.H. Beck, Warszawa, 2016.

- [Ustawa 1964] Ustawa z dnia 23 kwietnia 1964 roku Kodeks cywilny (Dz.U. z 2017 r. poz. 459 - tekst jednolity z późniejszymi zmianami).

- [Ustawa 1960] Ustawa z dnia 14 czerwca 1960 roku Kodeks postępowania administracyjnego (Dz.U. z 2017 r. poz. 1257 - tekst jednolity z późniejszymi zmianami).

- [Ustawa 1989] Ustawa z dnia 17 maja 1989 roku Prawo geodezyjne i kartograficzne (Dz.U. z 2017 r. poz. 2101 - tekst jednolity z późniejszymi zmianami).

- [Rozporządzenie 2001] Rozporządzenie Ministra Rozwoju Regionalnego i Budownictwa z dnia 29 marca 2001 roku w sprawie ewidencji gruntów i budynków (Dz.U. z 2016 r. poz. 1034 - tekst jednolity z późniejszymi zmianami).

- [Rozporządzenie 2013] Rozporządzenie Ministra Administracji i Cyfryzacji z dnia 29 listopada 2013 roku zmieniające rozporządzenie w sprawie ewidencji gruntów i budynków (Dz.U. z 2013 r. poz. 1551).

- [Rozporządzenie 1999] Rozporządzenie Ministrów Spraw Wewnętrznych i Administracji oraz Rolnictwa i Gospodarki Żywnościowej z dnia 14 kwietnia 1999 r. w sprawie rozgraniczania nieruchomości (Dz.U. z 1999 r. nr 45, poz. 453).

- [Ustawa 1982] Ustawa z dnia 26 marca 1982 roku o scalaniu i wymianie gruntów (Dz.U. z 2014 r. poz. 700 - tekst jednolity z późniejszymi zmianami).

- Centralna Baza Orzeczeń Sądów Administracyjnych. Dostęp on-line: http://orzeczenia.nsa.gov.pl.

- [II SA/Łd 61/10] - Wyrok WSA w Łodzi z 2010-06-30.

- [II OSK 195/16] - Wyrok NSA z 2016-09-14.

- $\quad$ [I OSK 2418/11] - Wyrok NSA z 2013-03-20.

- $\quad$ [I CKN 431/09] - Orzeczenie SN z 2000-08-07.

- $\quad$ [IV SA/Wa 255/16] - Wyrok WSA w Warszawie z 2016-05-18.

- $\quad$ [II SA/Ld 1077/97] - Wyrok NSA oz. w Łodzi z 2000-09-21.

- $\quad$ [III SA/Kr 504/08] - Wyrok WSA w Krakowie z 2009-06-16. 
- [III SA/Wr 146/04] - Wyrok WSA we Wrocławiu z 2006-01-26.

- [III CZP 98/12] - Uchwała SN z 2013-02-20.

\title{
The role of self-existent owner in selected administrative proceedings and legal surveying processes
}

\author{
Agnieszka Pęska-Siwik, Piotr Benduch \\ AGH University of Science and Technology, Faculty of Mining Surveying and Environmental \\ Engineering,Department of Geomatics, e-mail: peska@agh.edu.pl,pbenduch@agh.edu.pl
}

\begin{abstract}
Ownership is the most important property law. It constitutes the foundation of rightly functioning society and sustainable economy. The role of owner in legal surveying processes and administrative proceedings related to real estate is specifically described in the law. The situation is more complicated in case of grounds with unsettled legal status. When it is impossible to determine the owner of real estate in the cadastre the data of people and organization units who rule these grounds based on principles of self-existent ownership are revealed. The self-existent owner rules the real estate as owner, but his role in an administrative proceedings like real estate delimitation as well as in legal surveying processes is not unambiguous.

The goal of this article is the characterization of self-existent owner person and evaluation of his role during among others: determination of parcel boundaries, real estate delimitation, recovery of boundary marks or consolidation and exchange of lands. The rights and duties of self-existent owner are the main subject of the research. Possible legal solutions both: allowing efficient and effective performing of analysed procedures and proceedings as well as ensuring respect for property rights are also indicated and discussed.
\end{abstract}

Keywords: ownership, self-existent possession, dependant possession, real estate cadastre, determination of parcel boundaries. 